\title{
An Analysis of the Level of Transparency of Federal Universities' Websites in the South of Brazil
}

\author{
Natalia Kirchner de Azevedo ${ }^{1}$, Maurício Vasconcellos Leão Lyrio ${ }^{2}$, Rogério João Lunkes ${ }^{3} \&$ Luiz Alberton $^{3}$ \\ ${ }^{1}$ Accounting Master Program, Santa Catarina Federal University, Florianópolis, Brazil \\ ${ }^{2}$ Business Management Doctorate Program, Santa Catarina Federal University, Florianópolis, Brazil \\ ${ }^{3}$ Santa Catarina Federal University, Florianópolis, Brazil \\ Correspondence: Natalia Kirchner de Azevedo, Santa Catarina Federal University, Florianópolis, Brazil. E-mail: \\ kirchner.natalia@gmail.com
}

Received: July 17, 2016 Accepted: August 5, 2016 Online Published: October 30, 2016

doi:10.5539/par.v5n2p42 URL: http://dx.doi.org/10.5539/par.v5n2p42

\begin{abstract}
The internet contributes for the reduction of information asymmetries between the government and the society through the transparency, because provides an environment of analysis and reflection through the information publicized by the public managers. At any level of the Public Administration, the management must be efficient and transparent, so, the general objective of this research is to verify the level of transparency of websites of the federal universities in the South of Brazil in the year of 2014 based on what the Brazilian legislation determines. Through adaptation and application of the model proposed by Nunes (2013) for measurement of the level of transparency based on the Brazilian legislation, this work seeks to providing contribution to the researches about transparency in the public sector. In the evaluation the information content, usability of the websites and data availability were considered, distributed in a set of 25 descriptors based on the Brazilian legislation. Based on the analysis made, it has been possible to find out that the group of universities analyzed showed good transparency practices. Globally three universities showed excellent transparency level; yet most universities have improvements to be made in their websites. Federal University of Santa Catarina stood out for reaching the highest transparency level among federal universities in the south. To enable the construction of a transparency map, for future works is recommended the use of the model in universities from other regions of the country.
\end{abstract}

Keywords: transparency, public sector, federal universities

\section{Introduction}

The use of the Internet and electronic pages contributes for the improvement in the organizations' transparency efficiency, as well as favors the communication of these organizations with the society, enabling to reduce information asymmetry. As the information disclosure represents a kind of report, the highlighting and the disclosure of accounting information, along with management focused on transparency, it contributes for the legitimization of the organizational activities social value (Ingenhoff \& Koeling, 2009; Pacheco, 2012).

Lyrio, Lunkes and Taliani (2015) verified 30 years of studies about transparency, accountability and corruption in the public sector. According to the authors, new internet emerging technologies have an important role to approach the people to the government, thereby accountability and transparency have been showing relevance in fighting corruption, although it is necessary, besides information availability, participatory practices to help the development of democracy.

Therefore, transparency provides an environment of analysis and reflection through the information publicized by the public managers, but for that purpose it is necessary that the citizen receives the proper training through social participation mechanisms, so that they can enjoy the transparency instruments available (Figueiredo \& Santo, 2014). In this regard, management of the information publicized through the internet must take in account the quantity of information necessary for the free formation of public opinion (Rothberg \& Liberato, 2013).

When dealing with the issue of transparency in the universities scope, Cerrillo-i-Martínez (2015) argues that it does not depend only on providing information, but it also involves quality and access to this information through different mechanisms, considering that one university will be transparent as the university community and the society in general are effectively informed of its activity. 
Starting from the assumption that at any level of the Public Administration, the management must be efficient and transparent, and that the internet contributes for the reduction of information asymmetries between the government and the society, the question of research that leads this article comes up: "what is the level of transparency of websites of the Federal Universities in the southern Brazil?"

In this regard, the general objective of this research is to verify the level of transparency of websites of the federal universities in the South of Brazil in the year of 2014 based on what the Brazilian legislation determines. In order to obtain this purpose and to answer the research question the following specific objectives were defined: (I) check the compliance with the Brazilian legislation regarding information disclosure in universities websites; e (II) analyze the level of transparency of websites through the application of the model proposed by Nunes (2013).

After this introductory section, this study is organized in four sections. It initially presents the theoretical framework that substantiates aspects related to the higher education system and it reports findings from previous studies carried out in universities. Afterwards it presents the method and the procedures used in the research leading. Then it presents the results, in terms of analysis and discussion of the data collected . Lastly, it brings the final considerations and discusses the limitations and routings for future works.

\section{Theoretical Framework}

In this section some considerations about the higher education system in Brazil and previous studies about transparency in higher education institutions are made.

\subsection{Brazilian Higher Education System}

In the international scenario, higher education is understood as a public good, because besides aiming to educate the citizens it enables diversification and the use of new technologies (The United Nations Educational, Scientific and Cultural Organization [UNESCO], 2012). The State and the society have a duty to provide quality education for everybody, because many of the humanity problems, although they haven't been created or either can be solved by education, were probably maximized by the lack of education (Sobrinho, 2013).

In Brazil, the Federal Constitution, in its article 205, defines that education is a right of all and the State and the family's duty (Brazil, 1988). In this sense, Law number 9.394 was created, which establishes guidelines and bases for national education. One of the principles and goals of national education, treated in article 3 of the Law of Guidelines and Bases of National Education - LDB (Brazil, 1996), is the link among education, work and social practices.

In 1998 the World Conference about Higher Education approved the Referential Framework of Priority Action for the Change and Development of Higher Education by the publication of the "World Declaration about Higher Education for the XXI Century: View and Action". It has been established, in its article 13, that the higher education institutions must have autonomy in internal administration, but that autonomy must also correspond to the responsibility of transparency towards the government, the society, the students and the society in general (UNESCO, 1998).

\subsection{Previous studies about Transparency in Higher Education Institutions}

Previous researches already made in public universities show that the importance of attending the legislation and of the transparency in public accounts. Silveira and Taruco (2012) have explored the Brazilian federal universities' websites analyzing the disclosure of information and the accountability to the society regarding communication and public transparency. It has been found that despite the care with attending the legislation as to publication and offer of reports, there is a lack of initiatives to contextualize and explain the data aiming to make them more accessible. According to the study, the disclosure of information and the efforts made so that they get to the public are short if compared to the volume of information and the impact that it could create on society.

Aiming to verify the use of information technology for fighting corruption and as a support of access to public information, Martins (2014) observed that information technology influences public universities as it provides resources saving and improvement in services efficiency, because the celerity in data transmission promotes change in citizenship rights enabling broader inclusion of social actors. It has also been verified that federal universities with more master or doctor instructors tend to disclose more information.

Through an index, Pessôa and Almeida (2014) analyzed determinants of transparency of Brazilian federal universities, based on the disclosure of financial and non-financial information on their websites. The authors have found that the information related to the extension activities is more disclosed than the ones related to 
academic or administrative quality.

Zorzal and Rodrigues (2015) verified the management reports of federal universities, if they attend the national and international principles of government established for the public sector. The study pointed that meeting the principles of good government by the analyzed universities is not enough to reach the highest level of transparency, and that in order to improve this profile it is necessary to enlarge the transparency foreseen in the law of access to the information, so that the publicized information is timely, clear and accurate.

Jardim and Miranda (2015) analyzed the implementation of the Access to Information Law in Federal Universities in the state of Rio de Janeiro between May 2012 and May 2014. Thereby, they identified that active transparency, apart from the request of any citizen, has showed low score, suggesting higher monitoring of the law fulfillment by the responsible authorities. As for the level of passive transparency, when there is a request of any information by the citizen, the result of the research showed that the answers are provided in due time.

Cerrillo-y-Martínez (2015) has searched the role of transparency in the university, in the case of the Spanish university system. In this study it has been verified that transparency is more and more important as the dissemination of information brought forth by the universities in Spain, along with good administration and government, guarantee the efficiency and the quality in the provision of services of its activities. By analyzing the universities, the author has found that they have been making an effort to increase the information disclosed in their own website, however universities haven't been striving in using more mechanisms of information disclosure.

Gama and Rodrigues (2016) analyzed the implementation process of the Access to Information Law in a federal university and identified that the managers have had a broader perspective in the fulfillment of items such as transparency in the contracts accounts, balance sheet and auditing reports, and have identified challenges such as the lack of infrastructure of information systems. According to the research, the managers of this institution showed that the government needs to invest in other actions, besides the law, so that transparency becomes a fact.

In other research, Gama and Rodrigues (2016) analyzed transparency and the access to information from the perspective of the demand for accounting information in Brazilian federal universities and the research has indicated that in the two first years of the Access to Information Law the demand was $60 \%$ average, which indicates that the existence of instruments that compel transparency is not a guarantee of its implementation.

Using the model proposed by Nunes (2013), Staroscky, Lyrio, Lunkes, Cole \& Nunes (2015) evaluated the level of transparency demonstrated by the online portals of city governments that make up the Regional Development Bureau -RDB- of the municipality of Joinville, in the State of Santa Catarina, Brazil. The results showed, in general, a low level of transparency in the websites of the municipalities, thus, the evaluation indicates that $50 \%$ of municipalities did not disclose what Brazilian law requires.

Therefore, aiming to contribute to the research about transparency in public education institutions and to go ahead with the studies developed based on the model presented by Nunes (2013), this article aims to analyze the level of transparency in websites of federal universities in the southern Brazil.

\section{Method}

This section discusses how this research has been elaborated and the methodological procedures used in its conduction.

\subsection{Intervation Instrument}

Nunes (2013) has proposed a model based on the Brazilian legislation for the analysis of the elements available on the public entities websites. In her study the author has analyzed the levels of transparency in towns in the Southern Brazil with more than fifty thousand habitants. The present study continues the studies using the model proposed by Nunes (2013), once it aims to apply it in the analysis of the level of transparency on websites of federal universities in the South of Brazil, providing contribution to the researches about transparency in the public sector.

It is pointed out that the model proposed by Nunes (2013) considers the following legislations: Complementary Law $n^{\circ} 101 / 2000$, Complementary Law n ${ }^{\circ} 131 / 2009$, Decree 7.185/2010 and Law 12.527/2011. Considering the specificities related to the Higher Education Institutions' nature it has been necessary to adapt it to the universities' reality. For the evaluation of federal universities, the criteria were based on the "Guide for the creation of the section of access to information on federal organs and entities' websites", developed by the Federal Government Disciplinary Board based on the Access to Information Law's fulfillment. These evaluation 
criteria have been shown as descriptors in Nunes' model, containing a sequence of impact levels, which represent the level of transparency reached by a certain University in each of the criteria.

The evaluation has been carried out according to the three areas of concern proposed by Nunes, with the due adaptations. Chart 1 shows the list of minimum information that entities must disclose.

\begin{tabular}{|l|c|}
\hline \multicolumn{1}{|c|}{ EVALUATION CRITERIA } & $\begin{array}{c}\text { Evaluati } \\
\text { on Rate }\end{array}$ \\
\hline 1. INFORMATION CONTENTS & $\mathbf{7 0 \%}$ \\
\hline $\begin{array}{l}\text { 1.1 Budget Classification: } \\
\text { Budget Execution; Program (Projects, Actions e Activities); Nature of expense }\end{array}$ & $20 \%$ \\
\hline $\begin{array}{l}\text { 1.2 Hiring Processes } \\
\text { Bidding; Contracts; Agreements }\end{array}$ & $20 \%$ \\
\hline $\begin{array}{l}\text { 1.3 Compulsory information } \\
\text { Frequent questions; About the Access to Information Law; Citizen Information Service - SIC; } \\
\text { Classified Information }\end{array}$ & $10 \%$ \\
\hline $\begin{array}{l}\text { 1.4 Organizational Profile } \\
\text { Competences and Structure; Contact Information }\end{array}$ & $10 \%$ \\
\hline 1.5 Auditing & $20 \%$ \\
\hline $\begin{array}{l}\text { 1.6 Workforce } \\
\text { Payment; Staff; Servants description; Public Tenders }\end{array}$ & $20 \%$ \\
\hline 2. USABILITY & $\mathbf{1 5 \%}$ \\
\hline $\begin{array}{l}\text { 2.1 Access and Research } \\
\text { Access; Questions; Search tool }\end{array}$ & $34 \%$ \\
\hline $\begin{array}{l}\text { 2.2 Treatment of information } \\
\text { Saving reports; Authenticity of the information }\end{array}$ & $33 \%$ \\
\hline $\begin{array}{l}\text { 2.3 Feedback to the user } \\
\text { Comunications; Requests }\end{array}$ & $33 \%$ \\
\hline 3. DATA AVAILABILITY & $\mathbf{1 5 \%}$ \\
\hline 3.1 Historical series & $100 \%$ \\
\hline
\end{tabular}

Chart 1. Descriptors of evaluation of transparency in universities

Source: Adapted from Nunes (2013).

According to Nunes (2013), the compensation rates defined in the evaluation model consider the information contents, with $70 \%$ representation, and the usability and data availability, with $15 \%$ of representation each. The global evaluation of the model indicates the level of transparency of each website, varying from -50 to 150 points, according to the result of the level of impact on the evaluation of each descriptor.

In this research 25 descriptors of transparency evaluation have been numbered, in each concern area. These descriptors enable the measurement of the evaluation criterion, and each descriptor can be evaluated in five levels (Nunes, 2013).

The present study is limited to the Federal Universities in the South of Brazil. In order to get to the sample of universities a search in REUNI - Education Ministry website (Ministry of Education [MEC], 2015) has been made. From this verification, there is the sample of this research numbering eleven federal universities. Chart 2 lists the Universities that have composed the research sample, according to their State. 


\begin{tabular}{|c|l|c|}
\hline \multicolumn{1}{|c|}{ STATE } & \multicolumn{1}{|c|}{ UNIVERSITY } & ABBREVIATION \\
\hline Paraná - PR & Universidade Federal da Integração Latino-Americana & UNILA \\
\hline Paraná - PR & Universidade Federal do Paraná & UFPR \\
\hline Paraná - PR & Universidade Tecnológica Federal do Paraná & UTFPR \\
\hline Rio Grande do Sul - RS & Universidade Federal do Rio Grande do Sul & FURG \\
\hline Rio Grande do Sul - RS & Universidade Federal do Rio Grande & UFPEL \\
\hline Rio Grande do Sul - RS & Universidade Federal de Pelotas & UFSM \\
\hline Rio Grande do Sul - RS & Universidade Federal de Santa Maria & UFCSPA \\
\hline Rio Grande do Sul - RS & Universidade Federal de Ciências da Saúde de Porto Alegre & UNIPAMPA \\
\hline Rio Grande do Sul - RS & Universidade Federal do Pampa & UFFS \\
\hline Santa Catarina - SC & Universidade Federal da Fronteira Sul & UFSC \\
\hline Santa Catarina - SC & Universidade Federal de Santa Catarina & \\
\hline
\end{tabular}

Chart 2. Federal Universities in the South of Brazil

Source: Research data (2015).

The analysis of the descriptors of each university has been made from 01/15/2015 to 02/15/2015, and the contents analyzed comprised the 2014 period, when available. Each website has been accessed at least twice, in different days, to guarantee access because of communication problems on the website.

\section{Analysis of the Results}

Chart 3 shows the transparency levels of federal universities in the South of Brazil. The individual evaluation of each university can be identified, as well as the global evaluation of the state.

\begin{tabular}{|l|c|c|}
\hline \multicolumn{1}{|c|}{$\begin{array}{c}\text { STATE/ } \\
\text { UNIVERSITY }\end{array}$} & $\begin{array}{c}\text { INDIVUDUAL } \\
\text { EVALUATION }\end{array}$ & $\begin{array}{c}\text { GLOBAL } \\
\text { AVERAGE }\end{array}$ \\
\hline Paraná & & $\mathbf{6 2}$ \\
\hline UTFPR & 95 & \\
\hline UNILA & 53 & $\mathbf{6 6}$ \\
\hline UFPR & 37 & \\
\hline Rio Grande do Sul & 105 & \\
\hline UFCSPA & 102 & \\
\hline UFRGS & 75 & \\
\hline UNIPAMPA & 62 & $\mathbf{9 3}$ \\
\hline UFPEL & 35 & \\
\hline UFSM & 20 & \\
\hline FURG & & \\
\hline Santa Catarina & 111 & \\
\hline UFSC & 74 & \\
\hline UFFS & & \\
\hline
\end{tabular}

Chart 3. Level of Transparency in Federal Universities of Southern Brazil

Source: Research data (2015).

The state of Paraná - PR is the second State in quantity of federal universities in the South, with three universities UFPR, UNILA and UTFPR. In chart 3, it is observed that in Paraná all the universities were between neutral and good, it means, between 0 and 100 points, and had the average of 62 points. It can be pointed out that 
universities UFPR and UTFPR provide information about the hiring process, such as: biding, contract or agreement at excellent level.

The state of Rio Grande do Sul - RS shows the higher number of federal universities in the South, six universities were part of the evaluation among them: UFCSPA, UFSM, UFRGS, UFPEL, UNIPAMPA and FURG. It can be realized that Rio Grande do Sul is showing, on average, at least the compulsory information. Two universities had scores between good and excellent levels, UFCSPA with 105 points, the only one among all the universities analyzed that has reached excellent level of disclosure in the item salary, and UFRGS with 102 points, which provides all the information in the item hiring process at excellent level. The universities UNIPAMPA, UFPEL, UFSM and FURG have score between neutral and good level, reaching the least expected level of information.

The state of Santa Catarina - SC has two federal universities UFFS and UFSC. It is observed that Santa Catarina has average 93, the highest average in the States of the South. UFSC's result in the issue hiring process and compulsory information with excellent disclosure level can be stressed out, and in the issue usability the level was between neutral and good. Although in the usability evaluation it hasn't obtained excellent level, UFSC was the only university in the sample that has presented all the information in this area of concern.

By analyzing all the federal universities in the South of Brazil it has been possible to consolidate the level of transparency of their respective websites in a general ranking, shown in Table 1.

Table 1. General ranking of transparency in public universities in the South of Brazil

\begin{tabular}{clrrrr}
\hline \multicolumn{7}{c}{ EVALUATION CRITERIA } \\
\hline UNIVERSITY & Global Evaluation & Information Contents & Usability & Data Availability \\
\hline $1^{\circ}$ & UFSC & 111 & 121 & 28 & 150 \\
$2^{\circ}$ & UFCSPA & 105 & 113 & 100 & 150 \\
$3^{\circ}$ & UFRGS & 102 & 112 & 6 & 150 \\
$4^{\circ}$ & UTFPR & 95 & 108 & $\mathbf{- 2 5}$ & 150 \\
$5^{\circ}$ & UNIPAMPA & 75 & 11 & 31 & $\mathbf{- 5 0}$ \\
$6^{\circ}$ & UFFS & 74 & 108 & $\mathbf{- 8}$ & 0 \\
$7^{\circ}$ & UFPEL & 62 & 60 & $\mathbf{- 1 6}$ & 150 \\
$8^{\circ}$ & UNILA & 53 & 20 & 3 & 150 \\
$9^{\circ}$ & UFPR & 37 & 62 & $\mathbf{- 8}$ & 150 \\
$10^{\circ}$ & UFSM & 35 & 36 & 14 & $\mathbf{- 5 0}$ \\
$11^{\circ}$ & FURG & 20 & 81 & 12 & $\mathbf{- 5 0}$ \\
GENERAL AVERAGE & 70 & & & 82 \\
\hline
\end{tabular}

Source: Research data (2015).

It can be observed that most Universities show in the global evaluation level of performance between neutral and good, where three universities stand out in excellence level (UFSC, UFCSPA and UFRGS). Thus, the general average reached 70 points of global evaluation, which allows concluding that the level of transparency is adequate, because in average the minimum of legal demands is disclosed.

In $55 \%$ of the universities the information contents has reached levels between good and excellent, and in other $45 \%$ the level was between neutral and good. Therefore it can be concluded that the universities, besides disclosing the information demanded in information contents also disclose other information with quality, improving the access to information and transparency of their websites.

In Tables 2 and 3 the results of the concern area information contents are presented for each university. The criteria in each the Universities had negative score indicate that some information is not disclosed yet.

In Table 2, the descriptors from item 1.1 to item 1.3.3 are considered. It can be seen that the item budget execution showed excellent level in most universities, only UFSM and UNIPAMPA were leveled below neutral, it means, absence of information. It occurred because the budget execution disclosure was outdated, showing 
data for 2011 and 2012 respectively.

About the hiring processes, the criterion with highest average was 1.3.1 about the biding process, with score 118 reaching excellent level of disclosure. In the item agreement $36 \%$ of the universities haven't presented the information, but it can be due to the fact that this hiring type is not applied by the university.

Among the criteria of budget classification 1.2, the nature of the expense showed lower average compared to the program of budget execution, which shows that most universities provide the expenses according to the expense nature, with the possibility to perform the query only by period.

When analyzing Table 2, it can be observed that the classification criteria budget and hiring processes show good results, proven by the average. It is stressed that, by analyzing the trend, which indicates the figures that recur more often, seven evaluation criteria showed levels between good and excellent.

Table 2. Score in subdivision of informational content, items 1.1 to 1.3

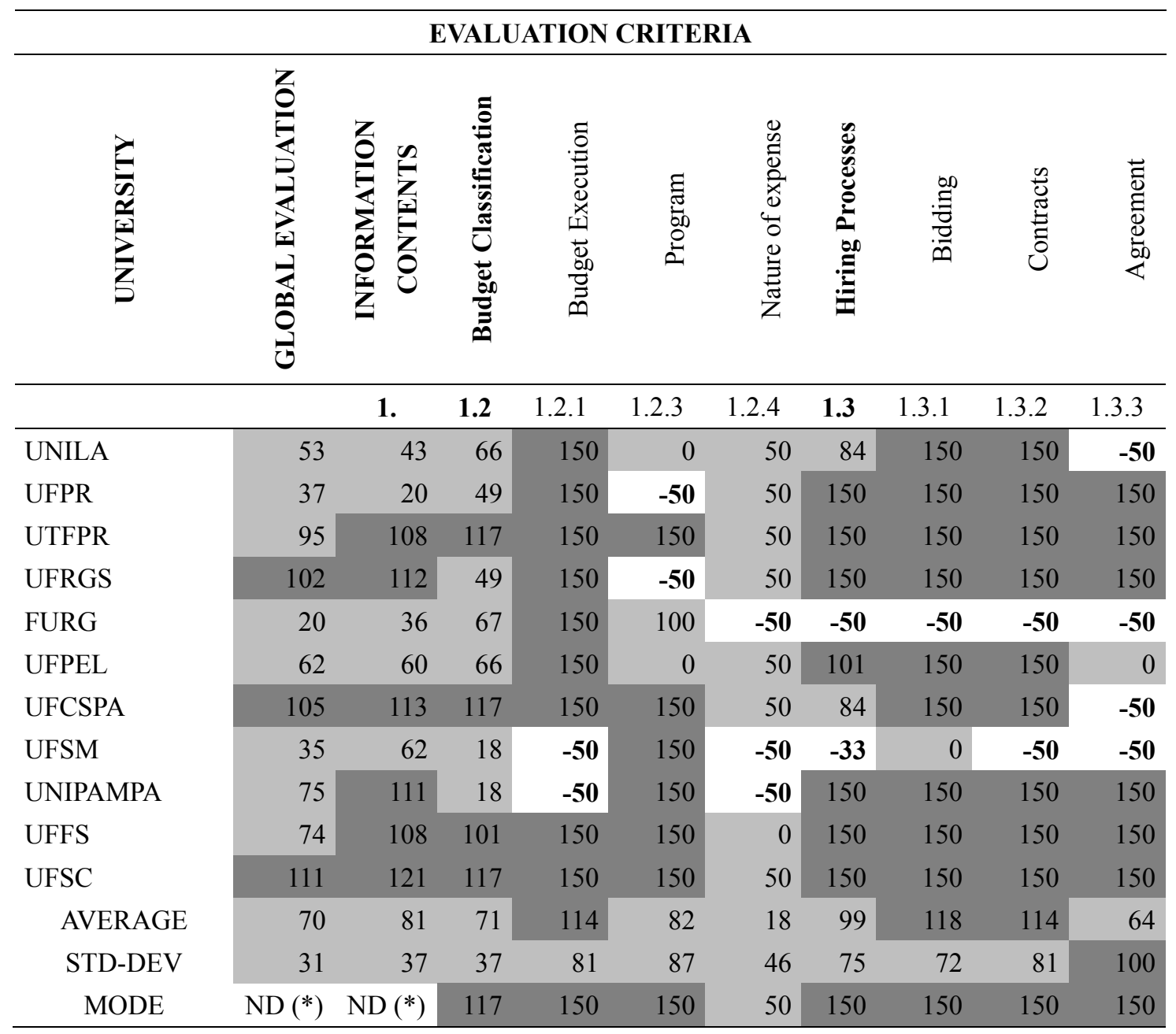

(*)In these items there hasn't been figures recurrence.

Source: Research data (2015).

Going on with the contents evaluation, in Table 3 UFPR stands out in a negative way, as it hasn't showed data in the compulsory information items, of organizational profile and auditing. As for the item workforce the only descriptor attended by UFPR was public tenders, reaching the highest score. Besides that, this descriptor was the only one among the information contents ones in which $100 \%$ of the universities showed the information at excellence level.

Among the compulsory information items, 1.6.3 was the one the universities have left most to be desired, as many of them did not show information about their operation, but showed a link directed to the System of 
Request for Access to Information of the Federal Executive Branch.

Frequent questions; About the Law of Access to Information; Citizen Information Service - SIC; Classified Information

Table 3. Score in subdivision information contents, items 1.6 to 1.10 .5

\begin{tabular}{|c|c|c|c|c|c|c|c|c|c|c|c|c|c|c|}
\hline \multicolumn{15}{|c|}{ EVALUATION CRITERIA } \\
\hline 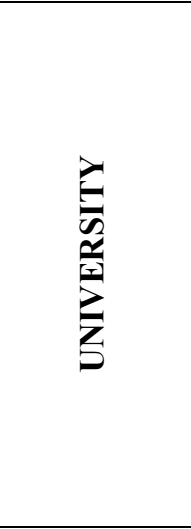 & 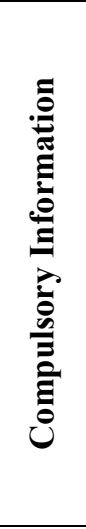 & 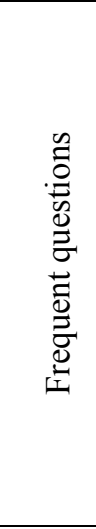 & 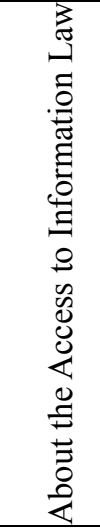 & 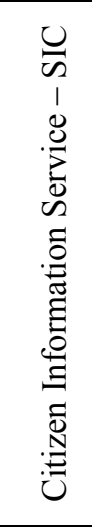 & 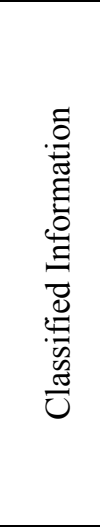 & 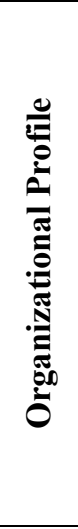 & 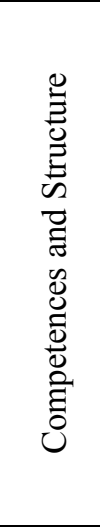 & 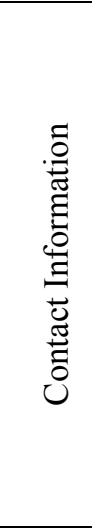 & $\stackrel{00}{:}$ & 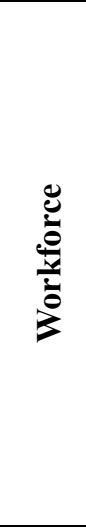 & 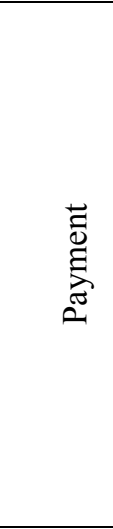 & 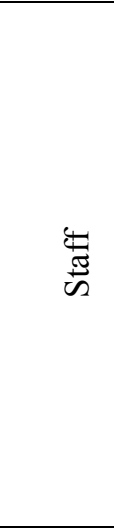 & 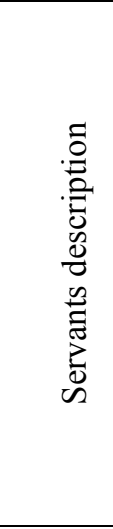 & $\begin{array}{l}0 \\
\overrightarrow{0} \\
\overline{0} \\
0 \\
0 \\
0 \\
0 \\
0\end{array}$ \\
\hline & 1.6 & 1.6 .1 & 1.6 .2 & 1.6 .3 & 1.6 .4 & 1.8 & 1.8 .1 & 1.8 .2 & 1.9 & 1.10 & 1.10 .1 & 1.10 .2 & 1.10 .3 & 1.10 .5 \\
\hline UNILA & 0 & -50 & 0 & 50 & 0 & 50 & 0 & 100 & -50 & 88 & 50 & 0 & 150 & 150 \\
\hline UFPR & -50 & -50 & -50 & -50 & -50 & -50 & -50 & -50 & -50 & 0 & -50 & -50 & -50 & 150 \\
\hline UTFPR & 50 & -50 & 150 & -50 & 150 & 25 & 100 & -50 & 150 & 88 & 50 & 0 & 150 & 150 \\
\hline UFRGS & 100 & -50 & 150 & 150 & 150 & 150 & 150 & 150 & 150 & 88 & 50 & 0 & 150 & 150 \\
\hline FURG & 100 & 150 & 150 & 150 & -50 & 150 & 150 & 150 & -50 & 88 & 50 & 0 & 150 & 150 \\
\hline UFPEL & 138 & 150 & 150 & 100 & 150 & 50 & 100 & 0 & -50 & 88 & 50 & 0 & 150 & 150 \\
\hline UFCSPA & 100 & 150 & 150 & -50 & 150 & 100 & 150 & 50 & 150 & 113 & 150 & 0 & 150 & 150 \\
\hline UFSM & 100 & 150 & 150 & -50 & 150 & 75 & 150 & 0 & 150 & 88 & 50 & 0 & 150 & 150 \\
\hline UNIPAMPA & 150 & 150 & 150 & 150 & 150 & 150 & 150 & 150 & 150 & 88 & 50 & 0 & 150 & 150 \\
\hline UFFS & 50 & -50 & 150 & -50 & 150 & 50 & 0 & 100 & 100 & 88 & 50 & 0 & 150 & 150 \\
\hline UFSC & 150 & 150 & 150 & 150 & 150 & 50 & 50 & 50 & 150 & 88 & 50 & 0 & 150 & 150 \\
\hline AVERAGE & 81 & 59 & 118 & 45 & 100 & 73 & 86 & 59 & 73 & 82 & 50 & -5 & 132 & 150 \\
\hline STD-DEV & 63 & 104 & 72 & 96 & 87 & 62 & 74 & 77 & 98 & 28 & 45 & 15 & 60 & 0 \\
\hline MODE & 100 & 150 & 150 & -50 & 150 & 50 & 150 & 150 & 150 & 88 & 50 & 0 & 150 & 150 \\
\hline
\end{tabular}

Source: Research data (2015).

In information contents, present in Table 4, items 2 and 3 take in account the information from the entire website. The concern area usability showed negative general evaluation for $36 \%$ of the universities, and the highest average, which indicates the attendance to the legislation, was for access information, which allows users access to the information, without need of registering besides having the website map and the possibility to change the language present in the website. 
Table 4. Score in subdivision of informational content, items 1.6 to 1.10 .5

\section{EVALUATION CRITERIA}

\begin{tabular}{|c|c|c|c|c|c|c|c|c|c|c|c|c|c|}
\hline 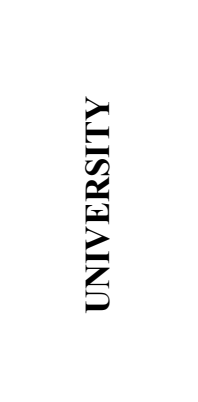 & $\vec{Z}$ & 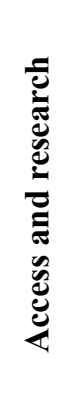 & 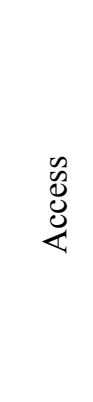 & 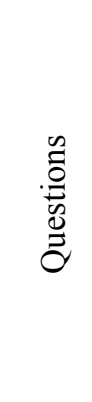 & $\begin{array}{c}\overrightarrow{8} \\
\stackrel{0}{0} \\
\overline{0} \\
\dot{0} \\
\tilde{D} \\
\tilde{n}\end{array}$ & 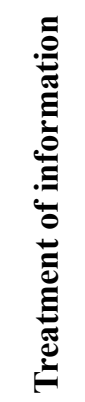 & 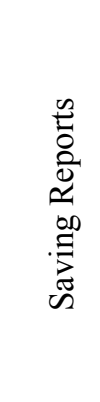 & 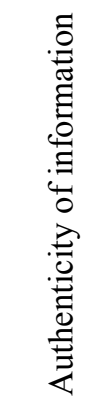 & 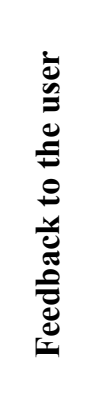 & 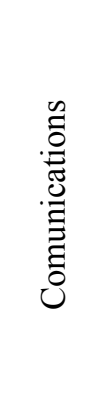 & 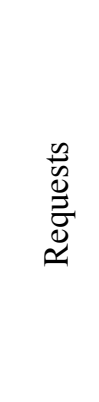 & 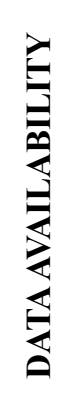 & 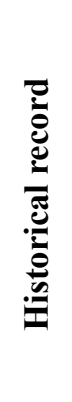 \\
\hline & 2. & 2.1 & 2.1 .1 & 2.1 .2 & 2.1 .3 & 2.2 & 2.2 .1 & 2.2 .2 & 2.3 & 2.3 .1 & 2.3 .2 & 3. & 3.2 \\
\hline UNILA & 3 & 35 & 150 & -50 & 0 & -25 & -50 & 0 & 0 & 0 & 0 & 150 & 150 \\
\hline UFPR & 6 & 67 & 50 & 150 & 0 & -25 & -50 & 0 & -25 & 0 & -50 & 150 & 150 \\
\hline UTFPR & -25 & 1 & 50 & -50 & 0 & -25 & -50 & 0 & -50 & -50 & -50 & 150 & 150 \\
\hline UFRGS & 6 & 68 & 150 & 50 & 0 & -25 & -50 & 0 & -25 & 0 & -50 & 150 & 150 \\
\hline FURG & 14 & 17 & 50 & -50 & 50 & -50 & -50 & -50 & 75 & 0 & 150 & -50 & -50 \\
\hline UFPEL & -16 & 1 & 50 & 50 & 0 & -25 & -50 & 0 & -25 & 0 & 100 & 150 & 150 \\
\hline UFCSPA & 100 & 100 & 50 & 150 & 150 & -25 & -50 & 0 & -25 & 0 & -50 & 150 & 150 \\
\hline UFSM & -8 & 1 & 50 & -50 & 0 & -25 & -50 & 0 & 0 & 0 & 0 & -50 & -50 \\
\hline UNIPAMPA & 31 & 68 & 150 & 50 & 0 & -25 & -50 & 0 & 50 & 50 & 50 & -50 & -50 \\
\hline UFFS & -8 & 1 & 50 & -50 & 0 & 0 & 0 & 0 & -25 & 0 & 0 & 0 & 0 \\
\hline UFSC & 28 & 34 & 50 & 50 & 0 & -25 & -50 & 0 & 75 & 0 & 150 & 150 & 150 \\
\hline AVERAGE & 12 & 35 & 77 & 23 & 18 & -25 & -45 & -5 & 2 & 0 & 23 & 82 & 82 \\
\hline STD-DEV & 34 & 35 & 47 & 79 & 46 & 11 & 15 & 15 & 44 & 22 & 79 & 96 & 96 \\
\hline MODE & -8 & 1 & 50 & -50 & 0 & -25 & -50 & 0 & -25 & 0 & -50 & 150 & 150 \\
\hline
\end{tabular}

Source: Research data (2015).

In item 2.2, treatment of information, only UFFS showed average in neutral level, when all the others have had negative score for not enabling to save reports in spreadsheets and texts. The attendance to legislation is pointed out concerning the items: access and search tool, in which all the universities meet the minimum required, thus have average between neutral and excellent.

Concerning data availability, $64 \%$ of universities provided information of the last five years or more, reaching level excellent of evaluation. However, $27 \%$ of the universities had negative score, it means, they haven't provided information concerning the two last years, among them two had outdated information, with last disclosure years 2011 and 2012.

\section{Conclusion}

The present study aimed to analyze the levels of transparency showed by the websites of federal universities in the South of Brazil. Based on its results it can be realized that there is culture of public transparency in the scope of federal universities in the southern Brazil. All the universities analyzed showed good transparency practices, reaching levels of transparency between good and excellent in the global evaluation, which indicates that, in average, they disclose the minimum of all information demanded by the legislation.

In global evaluation, $27 \%$ of the universities showed excellent level of transparency, revealing that the other universities can still improve, either with more detailing or historical series of the information, or with better access to the contents and forwarding requests of access to information. As a positive factor it is pointed out that information about public tenders are widely disclosed, $100 \%$ of the universities disclose information in excellence level, presenting information about ongoing tenders, programs, steps of the process and classified 
applicants.

In the usability and data availability areas, some universities showed negative average, it means, they haven't reached the minimum compulsory. One example is the reports saving, in which $91 \%$ of the universities haven't enabled saving the reports in spreadsheets or texts. As for the feedback to the user, $36 \%$ of the universities haven't enabled forwarding access to the information. This behavior shows that some information deserves better treatment, and that access of the user to the information must be improved, as well as data availability in formats that ease the analysis of the results of public management.

Concerning the research limitations, it has been verified in first place the number of universities analyzed, as the analysis has been restricted to the federal universities in the South of Brazil, hindering therefore the results generalization. Another limitation was the difficulty to collect the data, because many times the information was scattered around the website, making the access to the information difficult and demanding more willingness from the evaluator to find the necessary information for the research. By means of this limitation, it can be concluded that only the simple disclosure of data does not stimulate social participation, which is one of the rules of public transparency. The difficulty of access to certain information may, many times, discourage the involvement and the interest in following the public management. Therefore, it is important to favor access to the information in order to encourage the society participation in public policies.

From this research, it is recommended for future works the use of the model in universities from other regions of the country, in order to enable the construction of a transparency map of the federal universities in Brazil. It is suggested that the model is also applied by the entities themselves, to check their deficiencies and to be able to contribute for the process of reduction of information asymmetry. It is important to insist on the recommendation made by Nunes (2013) about the adoption of the model by the inspection bodies, to assist the auditing based on the information not disclosed by the entities.

\section{References}

Brazil. (1988). Constituição da República Federativa do Brasil: promulgada em 05 de outubro de 1988. Brasília: Senado Federal.

Brazil. (1996). Lei no 9.394, de 20 de dezembro de 1996. Estabelece as diretrizes e bases da educação nacional.

Cerrillo-Y-Martínez, A. (2015). The Role of Transparency in the University: the case of the Spanish University System. In Global Conference on Transparency Research. CH. Lugano: Università della Svizzera italiana.

Figueiredo, V. S., \& Santos, W. J. L. (2014). Transparência e participação social da gestão pública: análise crítica das propostas apresentadas na $1^{\text {a }}$ Conferência Nacional sobre Transparência Pública. Revista de Contabilidade e Controladoria, Curitiba, 6(1), 73-88. http://dx.doi.org/10.5380/rcc.v6i1.32082

Gama, J. R., \& Rodrigues, G. M. (2016). Transparência e acesso à informação: um estudo da demanda por informações contábeis nas universidades federais brasileiras. TransInformação, 28(1), 47-57. http://dx.doi.org/10.1590/2318-08892016002800004

Gama, J. R., \& Rodrigues, G. M. (2016). Perspectivas e Desafios na Transparência das Contas Públicas: um estudo numa Instituição de Ensino Superior brasileira. Encontros Bibli: revista eletrônica de biblioteconomia e ciência da informação, 21(45), 2-20. http://dx.doi.org/10.5007/1518-2924.2015v21n45p2

Ingenhoff, D., \& Koelling, A. M. (2009). The potential of Web sites as a relationship building tool for charitable fundraising NPOs. Public Relations Review, 35, 66-73. http://dx.doi.org/10.1016/j.pubrev.2008.09.023

Jardim, J. M., \& Miranda, V. L. (2015). A implantação da Lei de Acesso à Informação nas Universidades Federais do Estado do Rio de Janeiro. In XVI Encontro Nacional de Pesquisa em Ciência da Informação. BR. João Pessoa: Universidade Federal da Paraíba.

Lyrio, M. V. L., Lunkes, R. J., \& Taliani, E. T. C. (2015). Thirty years of studies on transparency, accountability and corruption in the public sector: lessons learned and opportunities for future research. In XIX IRSPM Conference. UK. Birmingham: University of Birmigham.

Martins, M. G. (2014). A tecnologia da informação inovando a transparência nas universidades públicas. In XIV Colóquio Internacional de Gestão Universitária. BR. Florianópolis: Universidade Federal de Santa Catarina.

Ministry of Education [MEC]. (2015). Mapa das universidades federais nos estados. Retrieved from http://reuni.mec.gov.br/index.php?option=com_wrapper\&view=wrapper\&Itemid=29

Nunes, G. S. F. (2013). Avaliação da transparência pública à luz da legislação brasileira: um estudo nos 
municípios da região sul do Brasil. pg 163. Thesis (Master of Accountancy). Graduate Program in Accounting. Universidade Federal de Santa Catarina, Florianópolis.

Pacheco, R. R. (2012). Nivel de Transparência de Fundações do Rio Grande do Sul. (Dissertação de mestrado não-publicada). Universidade do Vale do Rio dos Sinos, São Leopoldo, Brasil.

Pessôa, I. S., \& Almeida, J. E. F. (2014). Determinantes da Transparência das Universidades Federais Brasileiras. In XIV Congresso USP de Controladoria e Contabilidade. BR. São Paulo: Universidade de São Paulo.

Rothberg, D., \& Liberato, F. P. (2013). Comunicação pública, transparência e políticas públicas: avaliação de informações em sítios brasileiros de governo. Revista internacional de relaciones públicas, 6(3), 69-96.

Silveira, A. R., \& Taruco, L. M. R. (2012). A comunicação pública a serviço da transparência pública na internet: Estudo em Portais de Universidades Federais. Salão Internacional de Ensino, Pesquisa e Extensão.

Sobrinho, J. D. (2013). Educação Superior: bem público, equidade e democratização. Avaliação: Revista da Avaliação da Educação Superior, 18(1), 107-126. http://dx.doi.org/10.1590/S1414-40772013000100007

Staroscky, E. A., Lyrio, M. V. L., Lunkes, R. J., Cole, B. P., \& Nunes, G. S. F. (2015). An Analysis on the Web Portals of the Municipalities Comprising the Regional Development Bureau of Joinville (SC), Based on a Multicriteria Decisionmaking Model. Public Administration Research, 4(1), 24-37. http://dx.doi.org/10.5539/par.v4n2p45

The United Nations Educational, Scientific and Cultural Organization [UNESCO]. (2012). Desafios e perspectivas da educação superior brasileira para a próxima década. Retrieved from http://unesdoc.unesco.org/images/0021/002189/218964POR.pdf

The United Nations Educational, Scientific and Cultural Organization [UNESCO]. (1998). Declaração Mundial sobre Educação Superior no Século XXI: Visão e Ação 1998. Retrieved from http://www.direitoshumanos.usp.br/index.php/Direito-a-Educa\%C3\%A7\%C3\%A3o/declaracao-mundial-so bre-educacao-superior-no-seculo-xxi-visao-e-acao.html

Zorzal, L., \& Rodrigues, G. M. (2016). Transparência das informações das universidades federais: estudo dos relatórios de gestão à luz dos princípios de governança. Biblios: Journal of Librarianship and Information Science, 61, 1-18. http://dx.doi.org/ 10.5195/biblios.2015.253

\section{Copyrights}

Copyright for this article is retained by the author(s), with first publication rights granted to the journal.

This is an open-access article distributed under the terms and conditions of the Creative Commons Attribution license (http://creativecommons.org/licenses/by/4.0/). 